\title{
2,6-Bis(E)-4-Methylbenzylidine)-Cyclohexan-1-One As A Fluorescent-On Sensor For Ultra-Selective Detection Of Chromium Ion In Aqueous Media
}

Maria Sadia ( $\square$ mariasadia@gmail.com )

University of Malakand https://orcid.org/0000-0003-0818-170X

Jehangir Khan

University of Malakand

Syed Wadood Ali Shah

University of Malakand

Robina Naz

University of Malakand

Faiz Ali

University of Malakand

\section{Research Article}

Keywords: Fluorescent-on sensor, chromium, aqueous samples, sensing

Posted Date: July 7th, 2021

DOl: https://doi.org/10.21203/rs.3.rs-560875/v1

License: (c) (1) This work is licensed under a Creative Commons Attribution 4.0 International License. Read Full License 


\section{Abstract}

In current decade, curcumin and its analogues have been broadly used in biological field. However, there are relatively fewer studies regarding their fluorescence based applications for chromium ion sensing in water samples. This article, hereby, reports the synthesis, FTIR and ${ }^{1} \mathrm{H}-\mathrm{NMR}$ spectroscopic analyses and optical description of 2,6-bis(E)-4-methylbenzylidine)-cyclohexan-1-one (sensor C), as a fluorescence-on sensor for trace level sensing of chromium. The sensor $\mathrm{C}$ exhibited an ultra-selective response to chromium among the tested heavy metal ions. Different parameters were optimized like $\mathrm{pH}$, effect of concentration of sensor $\mathrm{C}$, metal ion and contact time. The binding stoichiometry of $\mathrm{C}: \mathrm{Cr}^{3+}$ was calculated to be 2:1 (Job's plot) with a significantly low detection limit of $2.3 \times 10^{-9} \mathrm{M}$. Sensor $\mathrm{C}$ were practically employed for detection of chromium in spiked water samples.

\section{Introduction}

Chromium is considered one of the major toxicant due to its high solubility and mobility in water. Most of the pollutants in environment are degraded gradually by living organisms into simpler harmless substances; but some pollutants including heavy metal ions like chromium are non-degradable [1, 2]. Chromium is mainly added to water bodies either from natural sources; like volcanic eruption, rock weathering or man-made activities; including mining operations, metal extraction, production of alloys, steel industries, and pigment producing factories, improper waste disposal, electroplating, synthetic fertilizers and other fields. In environment chromium readily gets dissolved in water and is persistent for longer period of time within the bodies of organisms [3,4], causing a number of disorders in organisms like tumors, gastrointestinal infections, ulceration, dermal irritation, lung cancer and anemia.

Several analytical methods such as absorption spectrometry [5], plasma mass spectroscopy [6], chemical reduction [7], adsorption [8], electrocoagulation [9], chemical precipitation [10], flotation [11], ion exchange [12], electrochemical [13] and amperometric analysis [14] have been applied for detection of chromium ions, but due to their time-consuming nature, complex operation, expensive instrumentations, sludge production, requirement of large amount of chemicals, and consequent risk of secondary pollutants, these techniques are not preferred for the trace detection of chromium. In the last few years, the development of optical sensors capable of sensing heavy metal ions is greatly demanded.

Among the metal ion sensors, fluorescence sensors have gained attention, since they contribute high sensitivity, lower cost, able to respond quickly, easily availability, excellent photo-physical properties, wide use, subsequent impact on the environment and nature, the easy operability, possibility of real time monitoring [15] and technological simplicity. The process of fluorescence based sensing is that upon light emission by fluorophore as soon as excited [16].

A number of fluorescent sensors have already been reported and were efficient employed for selective metal ion recognition and studies of these fluorescent probes yielded promising results in terms of specificity $[17,18]$. 
The design and synthesis of fluorescence based receptors for their applications for chromium ion detection in environmental samples is still demanding research topic, as the determination of chromium by spectrofluorimetry is rarely studied [19].

Curcumin has very exciting photo physical and fluorescence properties. Apart from their application in biological field, the chemically synthesized pi-extended derivatives of curcumin analogues, possessing variety of chemical sites can be used as a potential sensor for metal ion determination. In current study, we report the development of curcumin derivative as a potential fluorochrome possessing efficient optical properties and binding capability. Due to the presence of electron donor atoms in the chemical structure of curcumin, it can easily form stable complex with cations [20].

\section{Material And Methods}

\section{Required Materials}

All the chemicals and reagents used in the current study were used as received. Cyclohexanone (Merck) 4methylbenzaldehyde (Sigma Aldrich), sodium hydroxide (Alfa Aesar), methanol (Sigma Aldrich), Acetonitrile (Merck). Quartz cuvette was used for fluorometric chromium ion determination. All salts, in the form of sulphate, hydroxide and chloride form including $\mathrm{Cd}\left(\mathrm{SO}_{4}\right)_{2} \cdot 4 \mathrm{H}_{2} \mathrm{O}, \mathrm{Ca}\left(\mathrm{OH}_{3}\right)_{2} \cdot 4 \mathrm{H}_{2} \mathrm{O}$, $\left.\mathrm{Co}\left(\mathrm{OH}_{3}\right) \cdot 6 \mathrm{H}_{2} \mathrm{O}, \mathrm{Zn}\left(\mathrm{SO}_{4}\right)_{2} \cdot 6 \mathrm{H}_{2} \mathrm{O}, \mathrm{Cu}\left(\mathrm{SO}_{4}\right)_{2} \cdot 3 \mathrm{H}_{2} \mathrm{O}\right), \mathrm{Mn}\left(\mathrm{OH}_{3}\right)_{2} \cdot 4 \mathrm{H}_{2} \mathrm{O}$, and $\mathrm{Ni}\left(\mathrm{SO}_{4}\right)_{3} \cdot 6 \mathrm{H}_{2} \mathrm{O}, \mathrm{CrCl}_{3} \cdot 6 \mathrm{H}_{2} \mathrm{O}$ were purchased from $\mathrm{BDH}$ chemical England.

\section{Instrumentation}

Fluorescence analyses were performed with spectrofluorophotometermeter RF-5301PC (Shimadzu, Japan). Ultraviolet-Visible spectroscopic analysis was accomplished with double-beam UV-Visible spectrophotometer (Shimadzu, Japan) model 1601. For ${ }^{1} \mathrm{H}-\mathrm{NMR}$ and IR spectra characterization Bruker Advance $400 \mathrm{MHz}$ spectrometer and FTIR spectrophotometer Pretige 21 (Shimadzu, Japan) was used respectively.

\section{Solutions preparation for Spectroscopic measurements}

Stock solution of sensor $\mathrm{C}$ in acetonitrile, and metal ions solutions using respective salts of nickel, cadmium, lead, cerium, copper, mercury, zinc, and manganese and chromium were prepared in distilled water. Working solutions were prepared from stock solution by appropriate dilution.

\section{Sensor C synthesis and characterization}

The sensor C [2,6-bis(E)-4-methylbenzylidine)-cyclohexan-1-one] was synthesized with slight modification of already existing method in literature [21] by reacting aldehyde and ketone in specific ration i.e. 2: 1 . To a $12 \mathrm{mmol} 4$-methyl benzaldehyde $(0.26 \mathrm{~g}$ in $12 \mathrm{~mL}$ ethanol) was added $6 \mathrm{mmol}$ of cyclohexanone with continuous addition of sodium hydroxide ( $40 \%)$. The resulted mixture was refluxed for 4 hours and the progress of reaction was observed using TLC. The product formed was processed in ice to get the final 
products. Yellow colored pure crystals formed having melting point of $159^{\circ} \mathrm{C}$ (yield $78 \%$ ) and is given in (scheme 1). ${ }^{1} \mathrm{H}$ NMR: $\delta 7.78(\mathrm{~s}, 2 \mathrm{H},=\mathrm{CH}), 7.46(\mathrm{~d}, 4 \mathrm{H}, \mathrm{ArH}), 6.94(\mathrm{~d}, 4 \mathrm{H}, \mathrm{ArH}), 3.86\left(\mathrm{~s}, 6 \mathrm{H}, 2 \mathrm{CH}_{3}\right), 2.92$ (dd, $4 \mathrm{H}, J=14.6,2.7 \mathrm{~Hz}), 1.82\left(\mathrm{~m}, 2 \mathrm{H}, \mathrm{CH}_{2}\right)$ (Fig. S1) [22]. The IR (KBr) spectrum $\left(\mathrm{v} \mathrm{cm}^{-1}\right)$ : 1626-1642 (C = C Ar), 3000 - 2930 (C-H asymmetric), 1710 (C = 0) 3030, (C-H Ar) (Fig. S2) [23].

\section{Spectroscopic studies}

For exploring optical properties and sensing capability of sensor $\mathrm{C}$ for chromium detection UV-Vis and fluorescence spectrometry were used. The fluorescence and absorption spectra were taken in acetonitrile due to its freely solubility in it. In all of the spectroscopic experiments distilled water was used for metal solution and their spectra were recorded accordingly. For Uv/vis analysis, test solutions containing a fixed amount $(8 \mu \mathrm{M})$ of sensor $\mathrm{C}$ while chromium $(2-12 \mu \mathrm{M})$ concentration range were mixed and recorded. The fluorescence response of sensor $\mathrm{C}$ was monitored before and after mixing with different metal ions in distilled water. The mixtures were equilibrated at room temperature before measuring the fluorescence response. In addition, the practical applicability of sensor $\mathrm{C}$ for chromium ion determination in the vicinity of co-existing of similar metal cations in aqueous media was also investigated.

\section{Quantum yield calculation}

Rhodamine $6 \mathrm{G}$ dye was used as a standard possessing quantum yield $(\varphi) 95 \%$ for enumerating quantum yield of the sensor $\mathrm{C}$. For doing the experiment, Rhodamine $6 \mathrm{G}$ solution was prepared and its spectroscopic analysis (UV-Visible absorption and fluorescence) were performed. The quantum yield was determined with the help of the given formula

$$
\varphi_{\mathrm{C}}=\varphi_{\mathrm{R}}\left(\frac{\mathrm{I}_{\mathrm{C}}}{\mathrm{I}_{\mathrm{R}}}\right)\left(\frac{\eta_{\mathrm{c}}^{2}}{\eta_{\mathrm{R}}^{2}}\right)\left(\frac{A_{\mathrm{R}}}{\mathrm{Ac}_{\mathrm{c}}}\right)
$$

Where " $C$ " and " $R$ " represent sensor $C$ and dye respectively. "I" represent the integrated fluorescence intensity, " $\eta$ " correspond to refractive index of solvent and " $A$ " correspond to absorbance.

\section{Analytical sensitivity}

Stern Volmer plot analysis were performed for detection limit $(\delta)$ and quantification limit $(\beta)$ determination using Eqs. 2 and 3 respectively

$$
\begin{aligned}
& L O D=\frac{3 \delta}{\mathrm{S}} \\
& \beta=\frac{10 \delta}{\mathrm{S}}
\end{aligned}
$$

Where represent the standard deviation, and $\mathrm{S}$ being the slope of fluorescence response versus concentration curve. The respective experiment was performed seven times to examine the replicability of the system.

\section{Computation of binding constant}


To calculate approximately the binding constant of sensor C (Benesi-Hilderbrand plot) was drawn between fluorescence intensity and reciprocal of chromium concentration. The binding constant was attained using the given Eq. 4.

Binding constant $(B . C)=\frac{\text { Intercept }}{\text { Slope }}$

\section{Spiking of natural water samples}

Fluorescence spectroscopy was used for detecting the ability of the sensor $\mathrm{C}$ towards the ion of interest, Chromium, in real water samples. Therefore, the selected water samples (river water, Tap water) were used for spiking of different concentration of chromium (2-12) $\mu \mathrm{M}$ in the presence of $(8 \mu \mathrm{M})$ sensor $\mathrm{C}$ and the fluorescence response was measured at specific wavelengths of excitation and emission. For verification of the test results, all analysis were four times repeated.

\section{Results And Discussion}

\section{Ultraviolet-Visible study}

For the evaluation of the photophysical properties of sensor $\mathrm{C}$ and its chromium complex UV-Visible analysis was initially used. For considerable solubility and prospective applicability of sensor C, acetonitrile was selected as a solvent for sensor $C$ in the current study. Ultraviolet-Visible spectrum of sensor $\mathrm{C}$ was taken in the presence and absence of different concentration of chromium ions. The Uv/vis spectrum for sensor $C$ showed characteristic main absorption band $(\lambda \max )$ at $360 \mathrm{~nm}$.Upon addition of chromium solution bathochromic shift occurred and maximum absorption band appeared at $420 \mathrm{~nm}$,confirmingtheformation of chromium complex with sensor C (Fig. 1).Each time baseline was established by putting respective blanks in the reference slot.

\section{Cation sensing studies using fluorescence spectroscopy}

\section{Fluorescence-on studies by $\mathrm{Cr}^{3+}$ ion}

In our ongoing detection for a better understanding and a feasible intonation of the sensing ability of curcumin based fluorochrome, we have tagged curcumin based sensor with metal ion. In order to realize the photo physical properties of sensor $\mathrm{C}$ prior to metal ions recognition, the fluorescence response of free sensor $\mathrm{C}$ was taken. According to results obtained, sensor $\mathrm{C}$ displayed a very weak emission peak at $560 \mathrm{~nm}(\lambda e m)$. To investigate metal ion sensing by sensor $\mathrm{C}$, different heavy metal ions $\mathrm{Ni}^{2+}, \mathrm{Ce}^{3+}, \mathrm{Cu}^{2+}$, $\mathrm{Zn}^{2+}, \mathrm{Cd}^{2+}, \mathrm{Mn}^{2+}, \mathrm{Cr}^{3+}, \mathrm{Pb}^{2+}, \mathrm{Co}^{2+}(200 \mu \mathrm{M})$ were added to sensor $\mathrm{C}$ solution separately. The respective mixtures were allowed for 3 minutes to equilibrated, and were transferred into quartz cuvette separately by monitoring fluorescence intensity in the range of $400-700 \mathrm{~nm}$. The spectra obtained for all the studied metal was compared with the spectrum of sensor C. Accidentally, in our case, a prominent enhancement in fluorescence emission intensity was observedat $\lambda$ em $560 \mathrm{~nm}$ upon the addition of aqueous chromium ion $(200 \mu \mathrm{M})$ to sensor $\mathrm{C}$ solution. While no apparent enhancement in intensity was spotted for the rest of 
metal ions (Fig. 2). So among the studied metal ions only chromium form complex with sensor $\mathrm{C}$. This specific fluorescence-on response could be accredited to restriction of ICT phenomena. In the absence of chromium ions, due to ICT phenomena, a weak fluorescence was observed for sensor C. while in the presence of chromium ions ICT process is negligible and fluorescence intensity was extensively enhanced as the result of formation fa stable complex [24].

As discussed, we postulated that the apparent fluorescence enhancement of sensor $C$ could be ascribed to a distinctive chemical resemblance for chromium ion. It is presented in already reported articles, fluorescent molecules like sensor $\mathrm{C}$ retain certain preference for chromium ion, thus allow a superficial prejudice from its close neighbor $\mathrm{Fe}^{3+}$ along with other similar co-existing ions through fluorescence enhancement [25].

\section{pH study}

In the interests of avoiding interference in chromium ion recognition by protons, we focused on $\mathrm{pH}$ analysis on the fluorescence retaliation. The $\mathrm{pH}$ value of the test system was set to acquired value by $\mathrm{HCl}$ and $\mathrm{NaOH}$ solution. The sensor $\mathrm{C}(8 \mu \mathrm{M})$ did not change its fluorescent intensity from $\mathrm{pH}=1$ to 14 , indicating its consistency. The weak fluorescent response of sensor $\mathrm{C}$ may be owing to intra-molecular photo-induced electron transfer. However, sensor $\mathrm{C}$ complex with $(16 \mu \mathrm{M})$ chromium showed strong fluorescence at $\mathrm{pH} 8$, on account of its binding with $\mathrm{Cr}^{3+}$ leading to intra-molecular photo-induced electron transfer process inhibition. The chromium complex was unstable at lower $\mathrm{pH}$ thus displaying quenching in intensity as a result of protonation carbonyl oxygen that acts as binding site. By gradually increasing the $\mathrm{pH}$, the fluorescence intensity strappingly enhanced (Fig. 3). At pH 8, high stability was displayed by the chromium complex and maximum enhancement in intensity was observed at $\lambda$ em 560 $\mathrm{nm}$. While at $\mathrm{pH}>8$, a gradual decrease in intensity occurred due to formation of hydroxyl complexes that had poor solubility in water solution. From the results obtained, it can be assume that the synthesized sensor $\mathrm{C}$ can successfully be used for chromium ion determination at $\mathrm{pH} 8$ in aqueous samples [26].

\section{Sensor $\mathrm{C}$ concentration effect}

The determination of concentration effect of sensor Con fluorescence response of the sensor $\mathrm{C}-\mathrm{Cr}^{3+}$ complex is one of the important parameters in fluorimetric analyses. Working solution for analysis were prepared by keeping the chromium concentration constant $(16 \mu \mathrm{M})$, and varying the sensor $\mathrm{C}$ concentration in the range of $5-40 \mu \mathrm{M}$. The fluorescence emission intensity of each sample was monitored in 440-700 $\mathrm{nm}$ range (Fig. 4). With increasing concentration of sensor $\mathrm{C}$, a linear enhancement in the emission intensity was observed. At higher concentration, the fluorescence intensity remains constant.

\section{Quantitative study for $\mathrm{Cr}^{3+}$}

For the confirmation of sensitivity of sensor $\mathrm{C}$ toward chromium ion, fluorescence titration experiments were carried out. During these titrations, the sensor $\mathrm{C}$ concentration was kept constant while changing the 
chromium ions concentration from 1-15 $\mu \mathrm{M}$. A linear enhancement in the fluorescence intensity of chromium complex was noted at $560 \mathrm{~nm}(\lambda \mathrm{em})$ upon increasing chromium concentration (Fig. 5). Thus showing that sensor $\mathrm{C}$ can be used for quantitative determination of $\mathrm{Cr}^{3+}$.

\section{Binding mode study}

The binding stoichiometry between sensor $C$ and chromium was investigated using a Job's plot, $A$ Job's plot between the different mole fraction of sensor $\mathrm{C}-\mathrm{Cr}^{3+}$ complex versus respective emission intensities showed a maxima at 0.7 mole fraction indicating a 2:1 stoichiometric ration between sensor $\mathrm{C}$ and $\mathrm{Cr}^{3+}$ (Fig. 6).

This 2:1 binding ratio was further confirmed with the help of Benesi-Helderbrand plot. For this purpose, for determination of association constant the given equation was used

$$
\frac{F_{\max } F_{o}}{F-F_{\circ}}=1+\frac{1}{K\left[C r^{3+}\right]^{2}}
$$

Where $\mathrm{K}\left(\mathrm{M}^{-2}\right)$ represent association constant. $\mathrm{F}_{0}$, Fmax and $\mathrm{F}$ denote the emission intensity of free sensor $\mathrm{C}$, at $\left[\mathrm{Cr}^{3+}\right]$ in excess concentration and at different $\left[\mathrm{Cr}^{3+}\right](\lambda \mathrm{ex}=425 \mathrm{~nm}$ and $\lambda \mathrm{em}=560 \mathrm{~nm})$ respectively. The value of $\mathrm{K}$ was determined by plotting $\mathrm{Fmax}-\mathrm{F}_{\mathrm{o}} / \mathrm{F}-\mathrm{F}_{\mathrm{o}}$ versus $1 /\left[\mathrm{Cr}^{3+}\right]^{2}$, (Fig. 7). According to the Equation, data fitted linearly, showing good liner relationship with slope $6.515 \times 10^{-11}$, and intercept 1.539. The association constant calculated from the slope is found to be $1.53 \times 10^{10}$ thus confirming the 2:1 binding ratio between sensor $\mathrm{C}$ and $\mathrm{Cr}^{3+}$.

\section{The detecting mechanism of fluorescent sensor $\mathrm{C}$ forC ${ }^{3+}$}

The detecting mechanism of sensor $\mathrm{C}$ for $\mathrm{Cr}^{3+}$ ionwas suggested using the fluorescence spectra. The fluorescent response of the sensor $\mathrm{C}$ towards $\mathrm{Cr}^{3+}$ ionmay be allocated to intra molecular charge transfer (ICT). Before being coordinated with $\mathrm{Cr}^{3+}$ ions, sensor $\mathrm{C}$ displays a weak fluorescence emission spectrum due to lone electron pair of oxygen atom, which result in intra molecular charge transfer. Moreover, the lone electron pair of the oxygen atom give rise to a non-radiative process by the $n-\pi^{\star}$ transition, as a result quenching in fluorescence intensity takes place. On the other hand, after sensor $\mathrm{C}$ was coordinated to $\mathrm{Cr}^{3+}$ ion, radiation process was primarily viar- $\pi^{\star}$ transitions and the coordination complex was more rigid thus the ICT process was restricted upon addition of $\mathrm{Cr}^{3+}$ ionat the receptor site.

On the other hand, sensor $\mathrm{C}$ act as monodentate ligand as there is one potential coordination cite, the carbonyl oxygen. The coordination sphere of d-block elements like $\mathrm{Cr}$ is either 6 or 2 and complexes of chromium with both these coordination spheres have been reported [27-30]. Since the bulk of our sensor $\mathrm{C}$ is high so the bonding with chromium is expected to be strong and possible structures of sensor $\mathrm{C}-\mathrm{Cr}^{3+}$ complex have been proposed in the (Scheme 2). 
Table 1

Photophysical properties of sensor C

\begin{tabular}{|llllll|}
\hline Parameter & $\mathrm{C}: \mathrm{Cr}^{3+}$ & $\lambda e m(\mathrm{~nm})$ & $\lambda \operatorname{ex}(\mathrm{nm})$ & $\operatorname{LOD}\left(\mathrm{Cr}^{3+}\right)$ & Quantum yield (\%) \\
\hline Sensor C & $2: 1$ & 560 & 425 & $2.3 \times 10^{-9} \mathrm{M}$ & 72 \\
\hline
\end{tabular}

\section{Time study}

Rapid response time is highly preferred in flurorimetric studies, therefore the time effect on emission response of sensor $\mathrm{C}$ and its complex with chromium was studied in time range of $0-7 \mathrm{~min}$ for different concentrations of chromium. During the assay, the fluorescence emission response of sensor $\mathrm{C}$ remained unaffected with increasing time, whereas the complex showed a linear response in fluorescence intensity with time and maximum fluorescence response was observed at 2 min and then remained constant (Fig. 8). These results indicate effectivity of sensor $C$ for real time assay of chromium detection in environmental samples.

\section{Effect of competitive metal cations}

Competitive binding experiments were taken for evaluation of efficacy of the synthesized sensor $\mathrm{C}$ as a selective chromium ion sensor as sensor $\mathrm{C}$ should have the potential to detect chromium ions in the presence of co-existing metal cations. For this purpose, different commonly existing metal ions in water were selected like $\mathrm{Cu}^{2+}, \mathrm{Hg}^{2+}, \mathrm{Zn}^{2+}, \mathrm{Cd}^{2+}, \mathrm{Pb}^{2+}, \mathrm{Mn}^{2+}, \mathrm{Co}^{2+}, \mathrm{Ni}^{2+}$ including the closely related ions likeCe ${ }^{3+}$. The concentration of each interfering metal ion was taken 8 folds $(128 \mu \mathrm{M})$ as compared to chromium metal ion $(16 \mu \mathrm{M})$ while keeping the sensor $\mathrm{C}$ concentration constant $(8 \mu \mathrm{M})$. The fluorescence emission profiling was completed between $440-700 \mathrm{~nm}$ with $425 \mathrm{~nm} \lambda$ ex.

No interference in fluorescence results in terms of intensity occurred even in the presence of high concentrations of interfering ions (Fig. 9). Thus, the obtained results may indisputably provide the reported sensor $\mathrm{C}$ is particularly valuable in efficiently selective chromium ion determination from its chemically similar cations like cerium and other commonly found interfering ions. Therefore, it can be realistically incidental that the synthesized sensor $C$ exhibits an ultra-sensitive and highly selective fluorescence-on response toward chromium ion in aqueous samples.

\section{Reversibility of sensor C}

To determine whether the metal complex formation process is reversible or not, fluorescence emission titration experiment was performed using the sensor- $\mathrm{Cr}^{3+}$ complex with EDTA.

The reversibility of the designed fluorescence-based sensor is curricula for its economy and many times usage. In this regard, EDTA is added into sensor $\mathrm{C}$ combined with $\mathrm{Cr}^{3+}$ solution to confirm the effect of $\mathrm{Cr}^{3+}$ ions on the fluorescence response. When EDTA is added to the aqueous solution, the fluorescence spectrum is returned to its original state. The interaction between sensor $\mathrm{C}$ and $\mathrm{Cr}^{3+}$ ions is prevented by the formation of $\mathrm{Cr}^{3+}$-EDTA chelate. After the addition of EDTA, the fluorescence of sensor $\mathrm{C}$ is 
recovered. The fluorescence-on sensor $\mathrm{C}$ is proved to be reversible using turn off-on mechanism based on the fluorescence emission intensity measurement (Fig. 10). The experiments were repeated 4 times by getting the same results. Furthermore, since the fluorescence emission intensity was restored upon addition of EDTA, the sensing process was considered to be reversible rather than an ion-catalyzed reaction.

\section{Quantitative detection of $\mathrm{Cr}$ ion in aqueous samples}

To study in deep the suitability and on-field applicability of prepared sensor $\mathrm{C}$ for ultra-selective detection of chromium ion, the different water samples were spiked by adding chromium to have sample solutions in (1-10) $\mu \mathrm{M}$ conc. range. Accordingly, the results attained displayed a significant recovery of chromium ions from different environmental water samples (Fig. 11). Thus, we presented a cost efficient method for highly selective determination of $\mathrm{Cr}^{3+}$ ion in aqueous samples.

\section{Significance of Current Work}

As compared to other chromium ion detection methods (Table 2), the present methodology has the compensation in terms of linearity and ultra-low sensitivity. In addition, it display higher potential for chromium detection. 
Table 2

Comparison of some sensors for chromium ions determination

\begin{tabular}{|c|c|c|c|c|c|c|}
\hline Sensors & $\begin{array}{l}\text { Limit of } \\
\text { detection }\end{array}$ & $\begin{array}{l}\text { Fluores-cence } \\
\text { response }\end{array}$ & Analyte & $\begin{array}{l}\text { Optimal } \\
\text { pH }\end{array}$ & $\begin{array}{l}\text { Testing } \\
\text { media }\end{array}$ & Ref \\
\hline $\begin{array}{l}\text { 5,5'-bipyridy- } \\
\text { Idicar- } \\
\text { boxaldehyde }\end{array}$ & NA & turn-on & $\mathrm{Cr}^{3+}$ & 6 & Aqueous & [31] \\
\hline $\begin{array}{l}\text { carbon quantum } \\
\text { dots }\end{array}$ & $\frac{0.64 \times 10^{-6}}{M}$ & turn-off & $\mathrm{Cr}^{3+}$ & 8 & Aqueous & [32] \\
\hline $\begin{array}{l}\text { 5-((2-cyano- } \\
{[1,1-} \\
\text { biphenyl]-4-yl)- } \\
\text { methoxy)isophthalic } \\
\text { acid }\end{array}$ & $M^{1.4 \times 10^{-6}}$ & turn off & $\mathrm{Cr}^{3+}$ & 8 & Aqueous & [33] \\
\hline $\begin{array}{l}\text { rhodamine B } \\
\text { lactams }\end{array}$ & $1 \times 10^{-7} \mathrm{M}$ & turn on & $\mathrm{Cr}^{3+}$ & 7 & NA & [34] \\
\hline $\begin{array}{l}\text { asparagine } \\
\text { derivatives }\end{array}$ & $M^{1.6 \times 10^{-8}}$ & turn on & $\mathrm{Cr}^{3+}$ & 7 & NA & [35] \\
\hline $\begin{array}{l}\text { curcumin } \\
\text { derivative }\end{array}$ & $2.3 \times 10^{-9} \mathrm{M}$ & turn-on & $\mathrm{Cr}^{3+}$ & 8 & Aqueous & $\begin{array}{l}\text { Current } \\
\text { work }\end{array}$ \\
\hline
\end{tabular}

\section{Conclusion}

In summary, we have developed a sensor $\mathrm{C}$ for a possible $\mathrm{Cr}^{3+}$ ion-selective detection in aqueous samples. The sensor $\mathrm{C}$ exhibited remarkable sensing properties in terms of fluorescence response, sensitivity, selectivity and detection limit. Specially, sensor C showed a highly selective response for chromium among other interfering metal ions with limit of detection and limit of quantification $2.3 \times 10^{-9}$ $\mathrm{M}$ and $3.14 \times 10^{-8} \mathrm{M}$ respectively. Considering the photo-physical properties and the chemosensing capability, the highly emissive curcumin-based sensor C, [2,6-bis(E)-4-methylbenzylidine)-cyclohexan-1one] can be considered as one of the very promising candidate for chemosensing applications. Validity of the present method was effectively realized by real sample assay.

\section{Declarations}

\section{Declaration of interest}


The authors declare no competing financial interest.

\section{Acknowledgements}

We thankDepartment of Chemistry, University of Malakand for providing chemicals and research lab facility for conduction of the present work. We also extend our appreciation to Prof. Dr. Yuta Nishina and Dr. Rizwan Khan (Research Core for Interdisciplinary Sciences, Okayama University, Japan) for their help in characterization of the synthesized compounds.

\section{Supplementary data}

FTIR and ${ }^{1} \mathrm{H}-\mathrm{NMR}$ spectra of sensor $\mathrm{C}$, fluorescence emission profile as a function of $\mathrm{Cr}^{3+}$ ion, time course of the fluorescence response, titration curve from absorption analysis the response of sensor $\mathrm{C}$ towards $\mathrm{Cr}^{3+}$, titration curve of sensor S- $\mathrm{Cr}^{3+}$ complex, Jobs plot analysis, effect of $\mathrm{Cr}^{3+}$ ion concentration, BenesiHilderbrand plot, reversibility, $\mathrm{pH}$ study. Supplementary data to this article can be found online.

\section{Author Declarations}

\section{Funding}

There has been no significant financial support for conduction of current research work that could have influenced its outcomes.

\section{Conflicts of interest}

The authors declare that they have no conflicts of interest.

\section{Ethics declarations}

In the current study the procedure adopted is safe both for animals, humans and their environment.

\section{Consent to participate}

All the authors are consent to participated in the current research work. Consent for publication All the authors have given their consent of publishing this article in the said journal.

\section{Authors' contributions}

\section{Jehangir Khan}

Carried out the main experimental work.

\section{Maria Sadia}

Encouraged, supervised the findings of the work and took the lead in writing the manuscript. 


\section{Syed Wadood Ali Shah}

Supervised the project, conceived and planned the experiments.

\section{Robina Naz}

Contributed to the interpretation of the results.

\section{Faiz Ali}

Contributed to the final version of the manuscript.

All authors provided critical feedback and helped shape the research, analysis and manuscript.

\section{Data Availability}

All the data associated with this research has been presented in this paper.

\section{References}

1. Filice FP, Henderson JD, Li MS, Ding Z (2019) Correlating live cell viability with membrane permeability disruption induced by trivalent chromium. ACS omega 4(1):2142-2151

2. Bieber VS, Ozcelik E, Cox HJ, Ottley CJ, Ratan JK, Karaman M, Badyal S (2020) Capture and release recyclable dimethylaminomethyl-calixarene functional cloths for point-of-use removal of highly toxic chromium water pollutants. ACS Appl Mater Interfaces 12(46):52136-52145

3. Vellaichamy B, Periakaruppan $\mathrm{P}$, Nagulan B (2017) Reduction of $\mathrm{Cr}^{6+}$ from wastewater using a novel in situ-synthesized PANI/ $\mathrm{MnO}_{2} / \mathrm{TiO}_{2}$ nanocomposite: renewable, selective, stable, and synergistic catalysis ACS Sustain. Chem Eng 5(10):9313-9324

4. Barbosa RF, Souza AG, Maltez HF, Rosa DS (2020) Chromium removal from contaminated wastewaters using biodegradable membranes containing cellulose nanostructures. Chem Eng $\mathrm{J}$ 395:125-135

5. Suo L, Dong X, Gao X, Huang JX, Ye J, Zhao L (2019) Silica-coated magnetic graphene oxide nanocomposite based magnetic solid phase extraction of trace amounts of heavy metals in water samples prior to determination by inductively coupled plasma mass spectrometry. Microchem $\mathrm{J}$ 149:104-112

6. Lei C, Wang C, Chen W, He M, Huang B (2020) Polyaniline magnetic chitosan nanomaterials for highly efficient simultaneous adsorption and in-situ chemical reduction of hexavalent chromium: removal efficacy and mechanisms. Sci Total Environ 733:139-146

7. Ding J, Pu L, Wang Y, Wu B, Yu A, Zhang G, Gao X (2018) Adsorption and reduction of $\mathrm{Cr}$ (VI) together with $\mathrm{Cr}$ (III) sequestration by polyaniline confined in pores of polystyrene beads. Environ Sci Technol 52(21):12602-12611 
8. Khan SU, Islam DT, Farooqi IH, Ayub S, Basheer F (2019) Hexavalent chromium removal in an electrocoagulation column reactor: Process optimization using CCD, adsorption kinetics and $\mathrm{pH}$ modulated sludge formation. Process Saf Environ Prot 122:118-130

9. Kim T, Kim TK, Zoh KD (2020) Removal mechanism of heavy metal ( $\mathrm{Cu}, \mathrm{Ni}, \mathrm{Zn}$, and $\mathrm{Cr}$ ) in the presence of cyanide during electrocoagulation using Fe and Al electrodes. J Water Process Eng 33:101-109

10. Mahdavi S, Jalali M, Afkhami A (2013) Heavy metals removal from aqueous solutions using $\mathrm{TiO}_{2}$, $\mathrm{MgO}$, and $\mathrm{Al}_{2} \mathrm{O}_{3}$ nanoparticles. Chem Eng Commun 200(3):448-470

11. Kołodyńska D, Bąk JK, Razna JK, Pietrzak R (2017) Uptake of heavy metal ions from aqueous solutions by sorbents obtained from the spent ion exchange resins. Microporous Mesoporous Mater 244:127-136

12. Fu HR, Xu ZX, Zhang J (2015) water soluble metal-organic frameworks for fast and high dichromate trapping via sinsgle-crystal-single-crystal ion exchange. Chem Mat 27(1):205-210

13. Ouyang R, Bragg SA, chambers JQ (2012) Xue ZL Flower like self assembly of gold nanopartcles for high sensitive electrochemical detection of chromium (IV). Anal Chim Acta 722:1-7

14. Tumolo M, Ancona V, Paola DD, Losacco D, Campanale C, Massarelli C, Uricchio VF (2020) Chromium pollution in european water, sources, health risk, and remediation strategies: an overview. Int J Environ Res Public Health 17(15):54-68

15. Hao J, Li XY, Zhang Y, Dong WK (2018) A reversible bis(salamo)-based fluorescence sensor for selective detection of $\mathrm{Cd}^{2+}$ in water-containing systems and food samples. Mater 11(4):523-530

16. Acha ND, Elosua C, Corres JM, Arregui FJ (2019) Fluorescent sensors for the detection of heavy metal ions in aqueous media. Sens 19(3):599-604

17. Chu ZY, Wang WN, Zhang CY, Ruan J, Chen BJ, Xu HM, Qian HS (2019) Monitoring and removal of trace heavy metal ions via fluorescence resonance energy transfer mechanism: In case of silver ions. Chem Eng J 375:121-127

18. Chen S, Xue Z, Gao N, Yang X, Zang L (2020) Perylenediimide-based fluorescent and colorimetric sensors for environmental detection. Sens 20(3):917-923

19. Li E, Zeng X, Fan Y (2009) Removal of chromium ion (III) from aqueous solution by manganese oxide and microemulsion modified diatomite. Desalination 238(1-3):158-165

20. Prohl M, Schubert US, Weigand W, Gottschaldt M (2016) Metal complexes of curcumin and curcumin derivatives for molecular imaging and anticancer therapy. Coord Chem Rev 307:32-41

21. Carmona-Vargas CC, Alves DC, Brocksom TJ, Oliveira KT (2017) Combining batch and continuous flow setups in the end-to-end synthesis of naturally occurring curcuminoids. React Chem Eng 2(3):366-374

22. Badal MMR, Ashekul IHM, Maniruzzaman M, Abu Yousuf M (2020) Acidochromic behavior of dibenzylidene cyclohexanone-based bischalcone: experimental and theoretical study. ACS omega 5(36):22978-22983 
23. Tamang N, Ramamoorthy G, Joshi M, Choudury AR, Kumar S, Golakoti NR, Doble M (2020) Diarylidenecyclopentanone derivatives as potent anti-inflammatory and anticancer agents. Med Chem Res 29(9):1579-1589

24. Zhang H, Liu Q, Wang T, Yun Z, Li G, Liu J, Jiang G (2013) Facile preparation of glutathione-stabilized gold nanoclusters for selective determination of chromium (III) and chromium (VI) in environmental water samples. Anal Chim Acta 770:140-146

25. Dutta A, Mahapatra M, Deb M, Mitra M, Dutta S, Chattopadhyay PK, Singha NR (2020) Fluorescent terpolymers using two non-emissive monomers for $\mathrm{Cr}(\mathrm{III})$ sensors, removal, and bio-imaging. ACS Biomater Sci Eng 6(3):1397-1407

26. Saini A, Bhasin AK, Singh N, Kaur N (2016) Development of a $\operatorname{Cr}(I I I)$ ion selective fluorescence probe using organic nanoparticles and its real time applicability. New J Chem 40(1):278-284

27. Carney MJ, Robertson NJ, Halfen JA, Zakharov LN, Rheingold AL (2004) Octahedral chromium (III) complexes supported by bis (2-pyridylmethyl) amines: ligand influence on coordination geometry and ethylene polymerization activity. Organometallics 23(26):6184-6190

28. Doistau B, Collet G, Bolomey EA, Sadat-Noorbakhsh V, Besnard C, Piguet C (2018) Heteroleptic terbidentate $\mathrm{Cr}$ (III) complexes as tunable optical sensitizers. Inorg Chem 57(22):14362-14373

29. Al Thagfi J, Lavoie GG (2012) Synthesis, characterization, and ethylene polymerization studies of chromium, iron, and cobalt complexes containing 1, 3-Bis (imino)-N-heterocyclic carbene ligands. Organometallics 31(6):2463-2469

30. Park JE, Kang SK, Woo JO, Son KS (2015) Highly active chromium (III) complexes based on tridentate pyrazolyl pyridyl ligands for ethylene polymerization and oligomerization. Dalton Trans 44(21):9964-9969

31. Balamurugan G, Velmathi S (2018) Coplanarity driven fluorescence turn-on sensor for chromium (III) and its application for bio-imaging. Photochem Photobiol Sci 17(2):239-244

32. Feng S, Gao Z, Liu H, Huang J, Li X, Yang Y (2019) Feasibility of detection valence speciation of $\mathrm{Cr}$ (III) and $\mathrm{Cr}(\mathrm{VI})$ in environmental samples by spectrofluorimetric method with fluorescent carbon quantum dots. Spectrochim Acta A Mol Biomol Spectrosc 212:286-292

33. Sun Z, Yang M, Ma Y, Li L (2017) Multi-responsive luminescent sensors based on two-dimensional lanthanide-metal organic frameworks for highly selective and sensitive detection of $\mathrm{Cr}$ (III) and $\mathrm{Cr}$ (VI) ions and benzaldehyde. Cryst Growth Des 17(8):4326-4335

34. Zheng X, Zhang W, Mu L, Zeng X, Xue S, Tao Z, Yamatob T (2010) A novel rhodamine-based thiacalix [4] arene fluorescent sensor for $\mathrm{Fe}^{3+}$ and $\mathrm{Cr}^{3+}$. J Incl Phenom Macrocycl Chem 68(1):139-146

35. Esteves Cl, Raposo MM, Costa SP (2011) Novel highly emissive non-proteinogenic amino acids: synthesis of 1, 3, 4-thiadiazolyl asparagines and evaluation as fluorimetric chemosensors for biologically relevant transition metal cations. Amino Acids 40(4):1065-1075

\section{Figures}




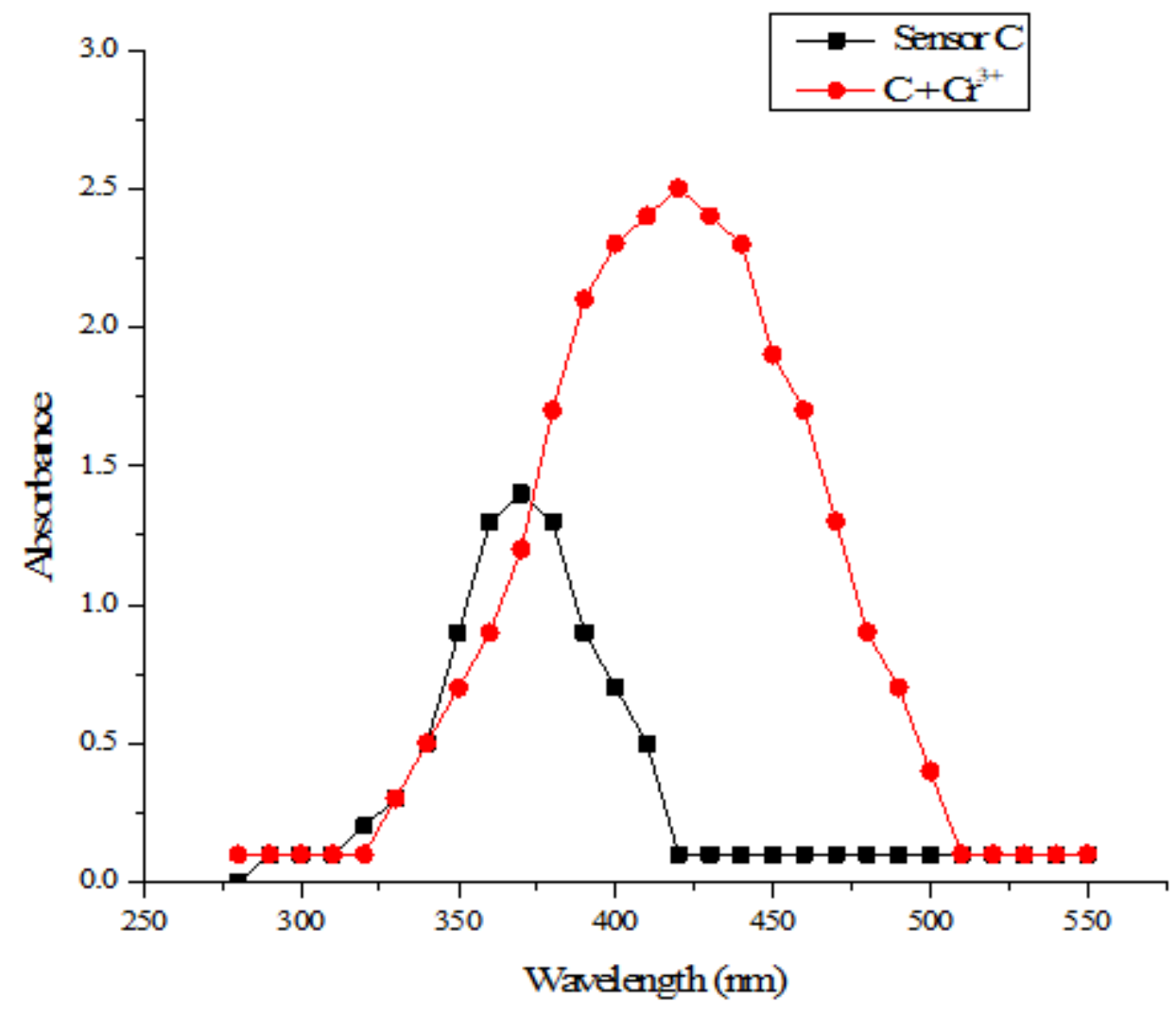

Figure 1

UV visible analysis of sensor $\mathrm{C}$ and its chromium complex

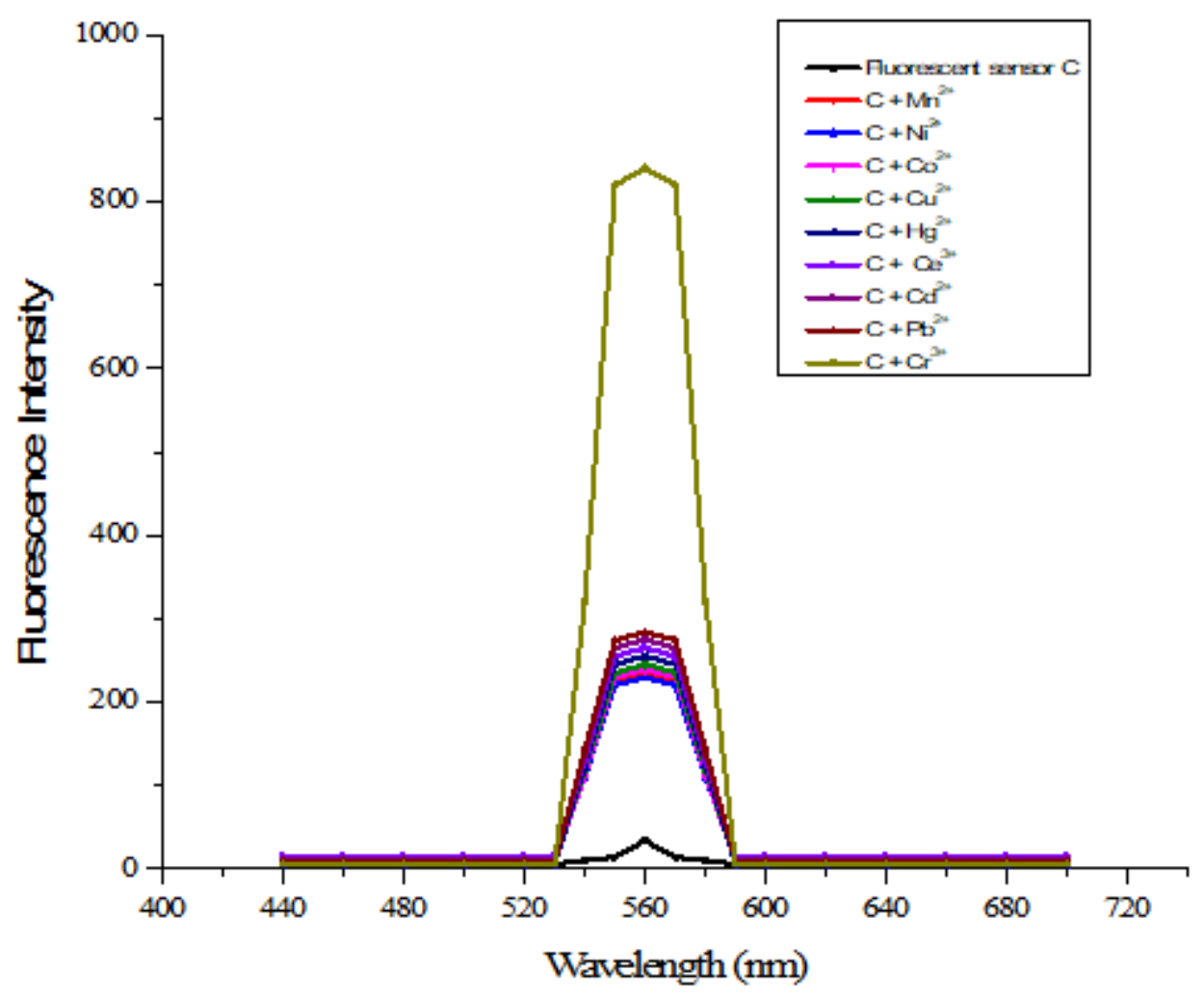

Figure 2 
Fluorescence-on study of sensor $C$ showing maximum fluorescence intensity at $\lambda$ em560 nmforchromiumusingsensorC, $(8 \mu \mathrm{M})$ and metal ions $(200 \mu \mathrm{M})$.

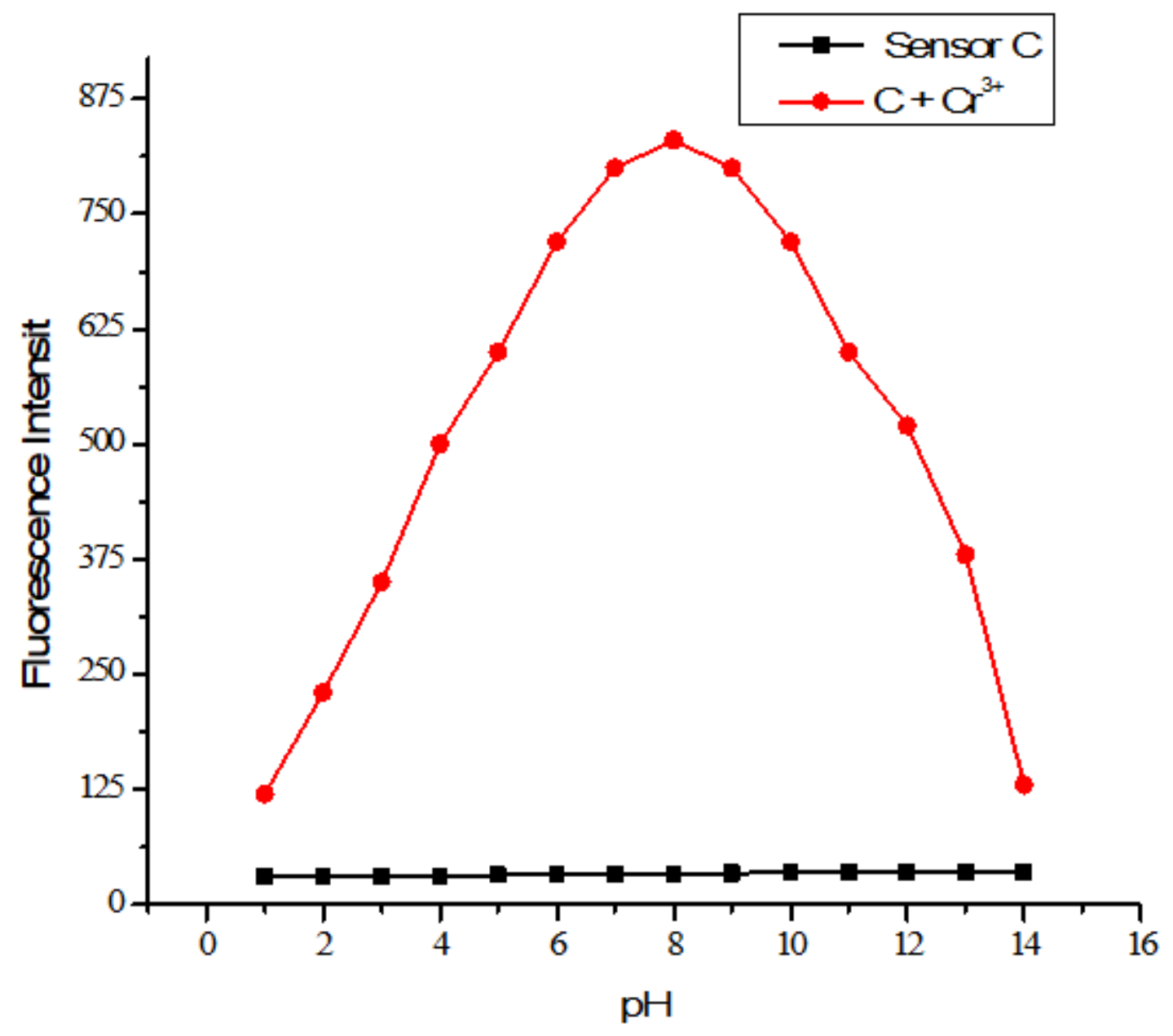

Figure 3

Changes in fluorescence emission intensity of sensor $\mathrm{C}$ and its complex with chromium with change in $\mathrm{pH}$ from 1-14at wavelengths of emission $560 \mathrm{~nm}$. 


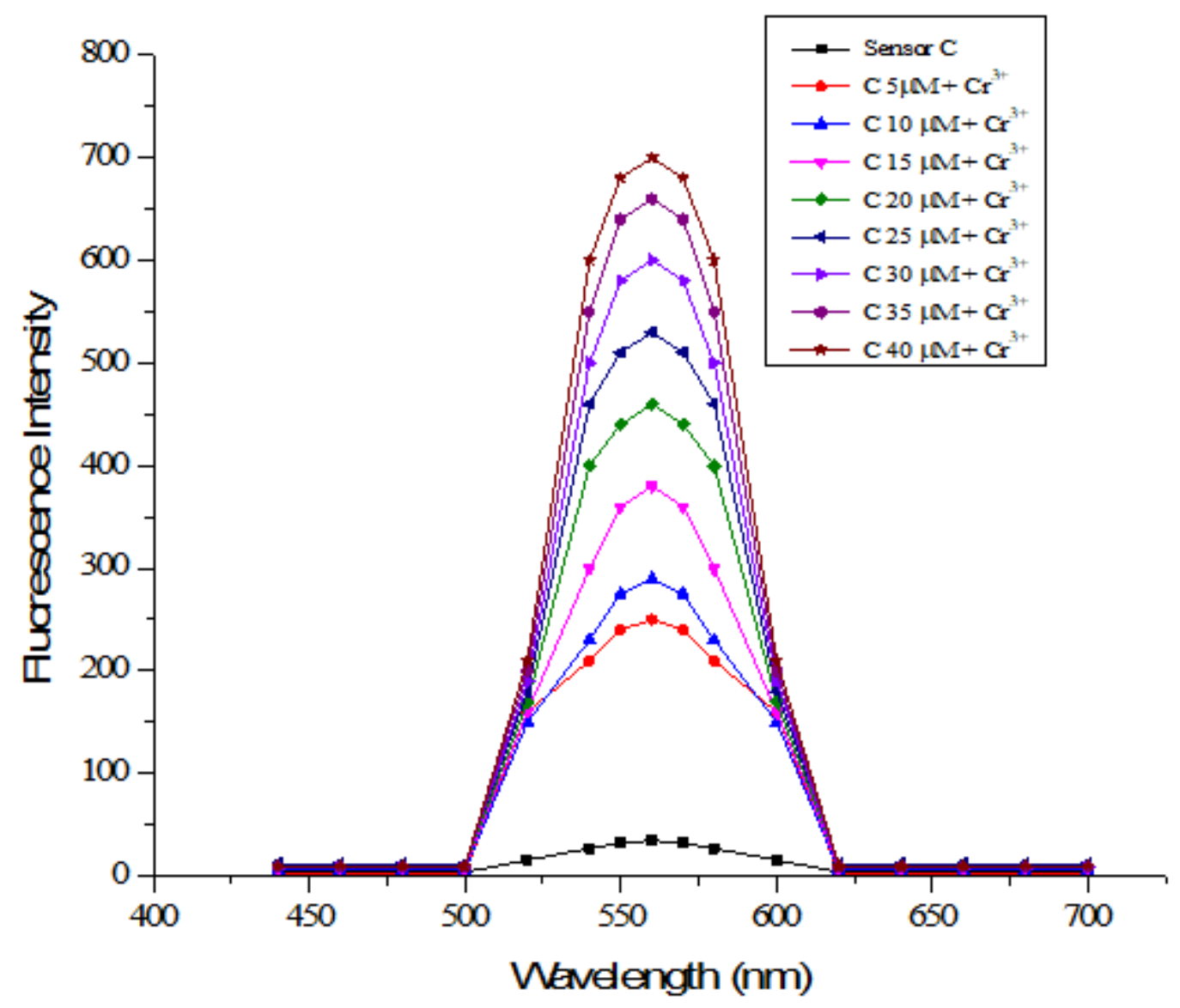

Figure 4

Fluorescence emission profile of sensor $\mathrm{C}-\mathrm{Cr} 3+$ complex as a function of sensor $\mathrm{C}$ concentration $(\lambda \mathrm{em}=$ $560 \mathrm{~nm}$ and $\lambda \mathrm{ex}=425 \mathrm{~nm}$ ) 


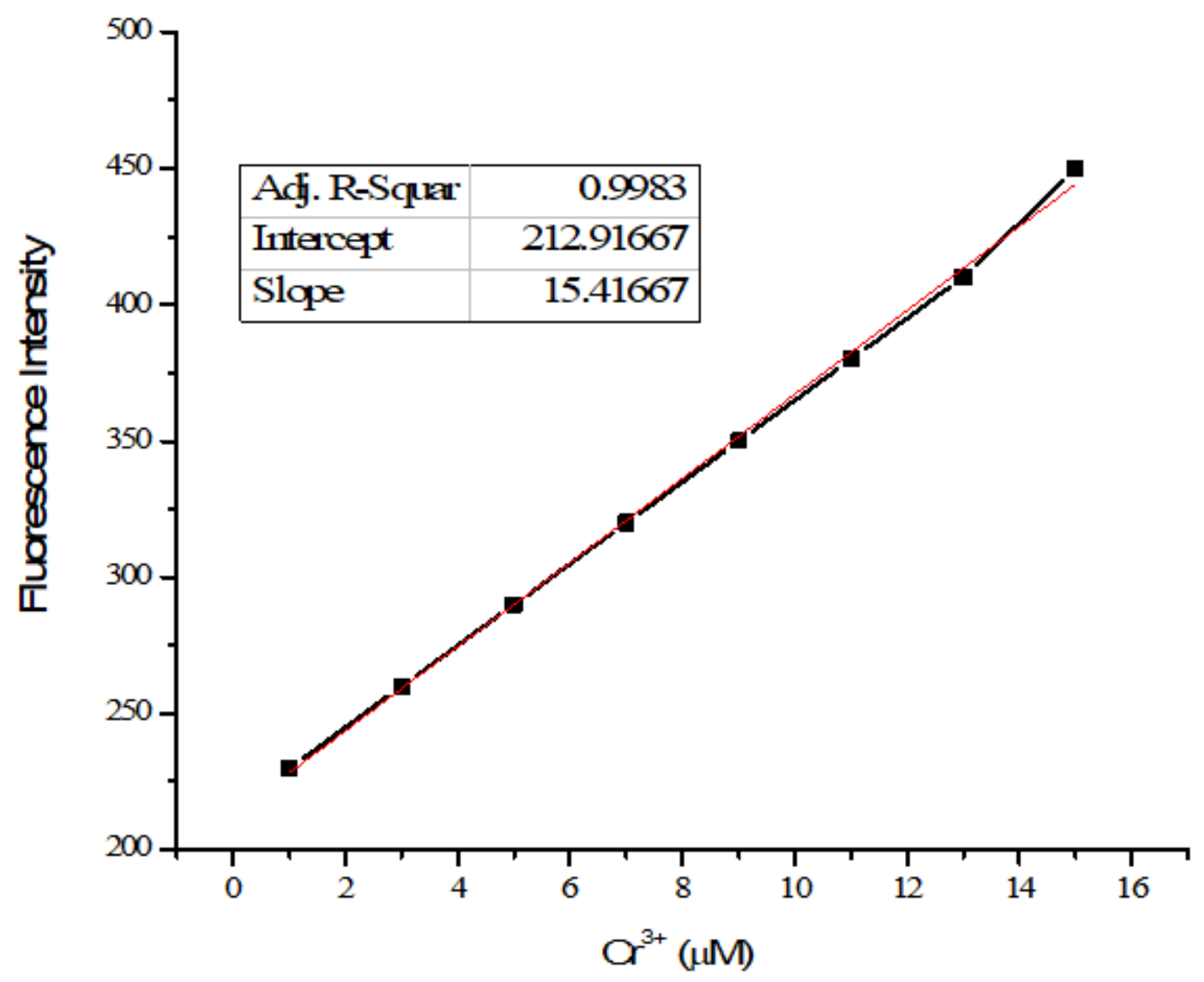

Figure 5

Fluorescence emission profile of sensor $\mathrm{C}-\mathrm{Cr} 3+$ complex as a function of chromium ions concentration $(\lambda e m=560 \mathrm{~nm}$ and $\lambda \mathrm{ex}=425 \mathrm{~nm})$. 


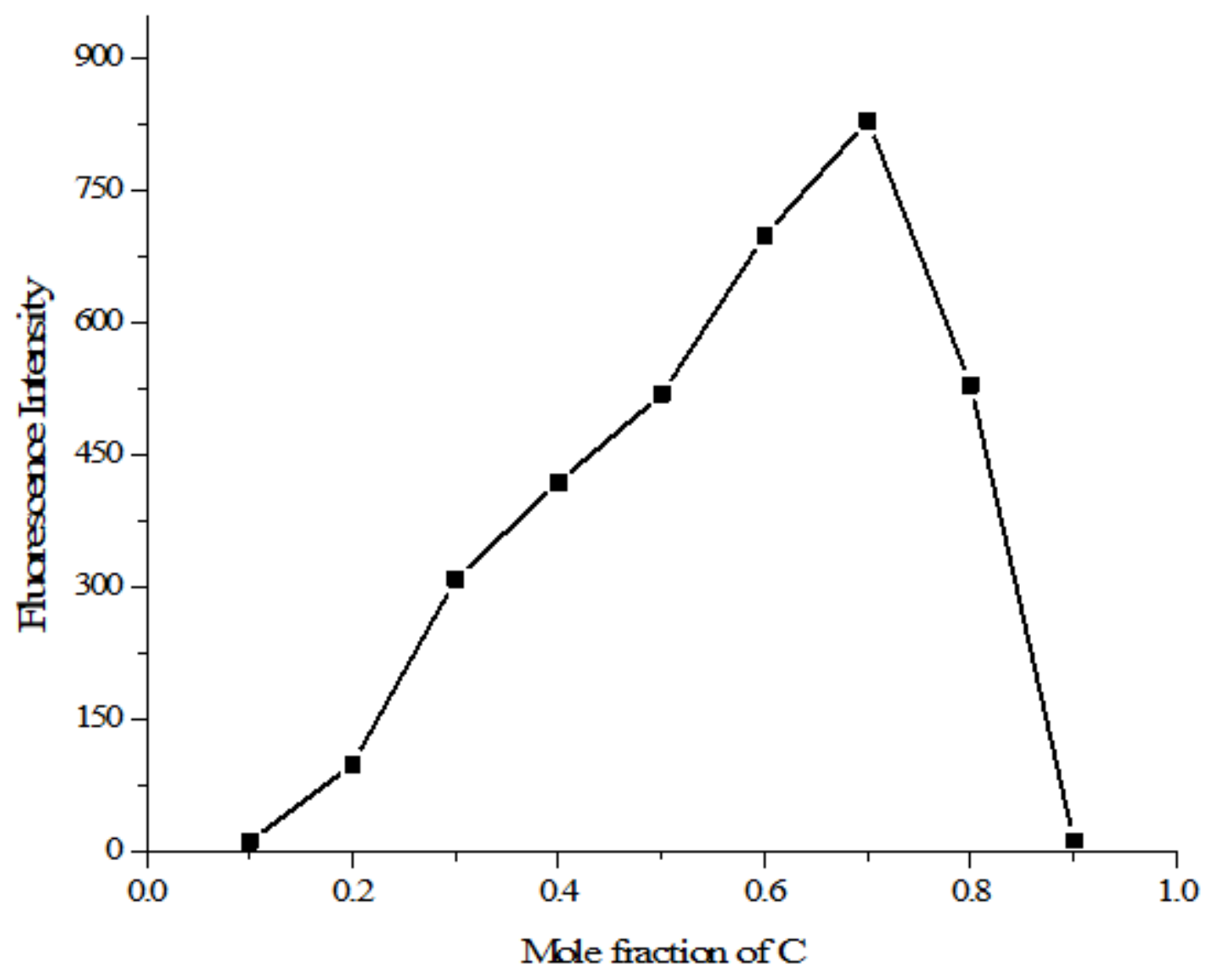

Figure 6

The job's plot examined between sensor $\mathrm{C}$ and $\mathrm{Cr} 3+$, indicating the 2:1 stoichiometry, which was carried out by fluorescence spectra $(\lambda \mathrm{em}=560 \mathrm{~nm})$. 


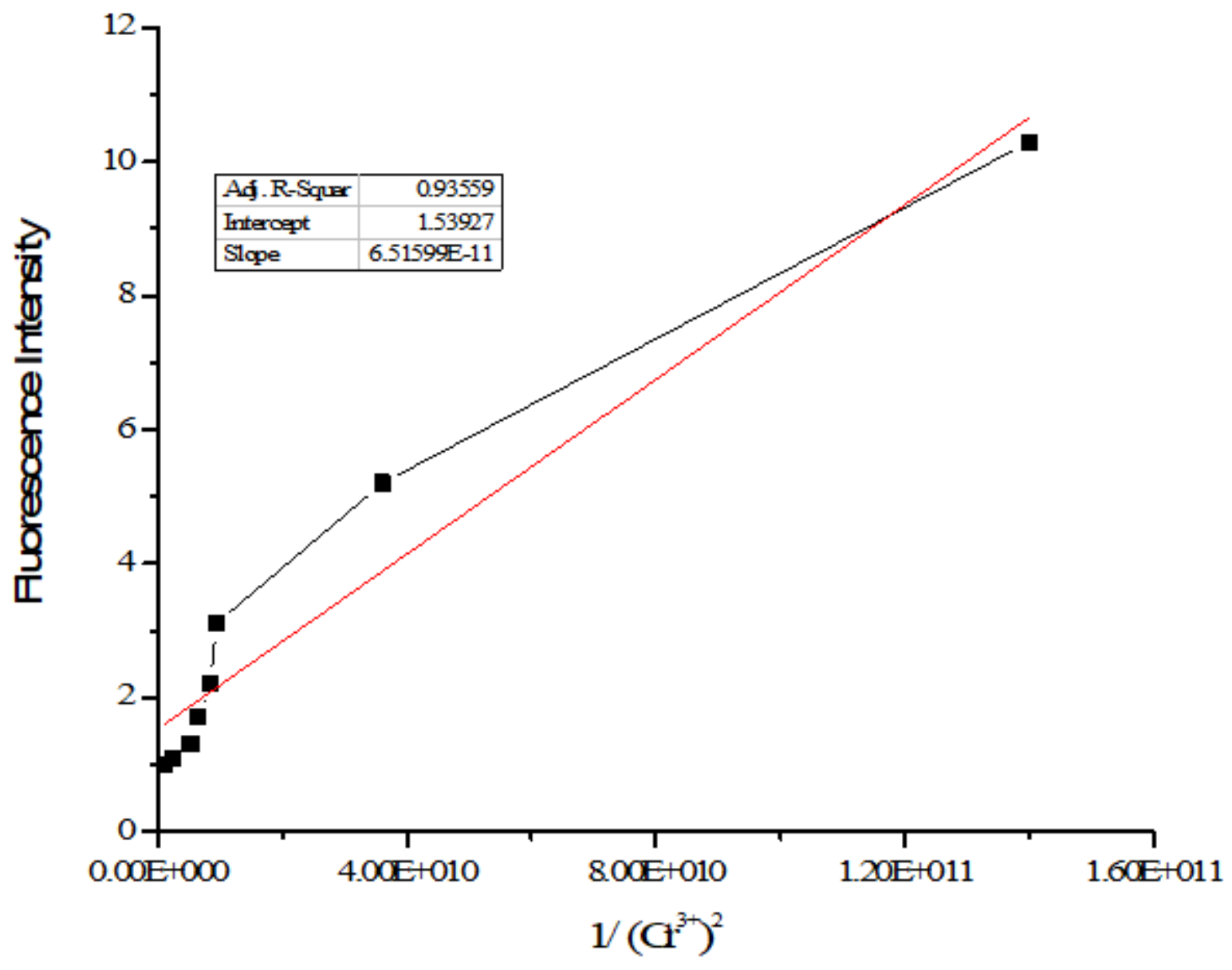

Figure 7

Bensi-Helderbrand Plot analysis for association constant determination 


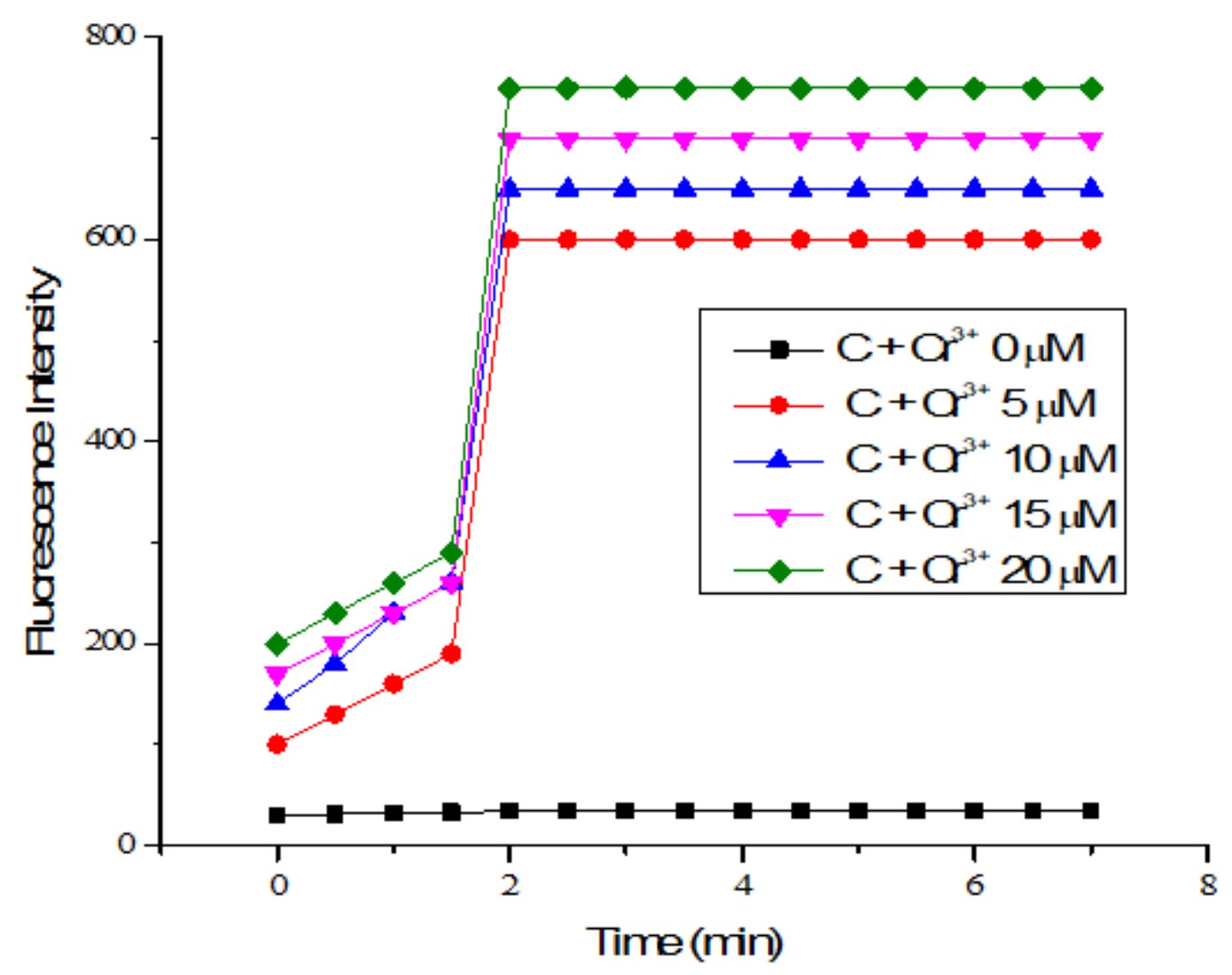

Figure 8

Effect of time on the fluorescence response of sensor $\mathrm{C}(8 \mu \mathrm{M})$ with chromium concentration in the range of $(0-20 \mu \mathrm{M})$ at $\lambda$ em560 $\mathrm{nm}$. 


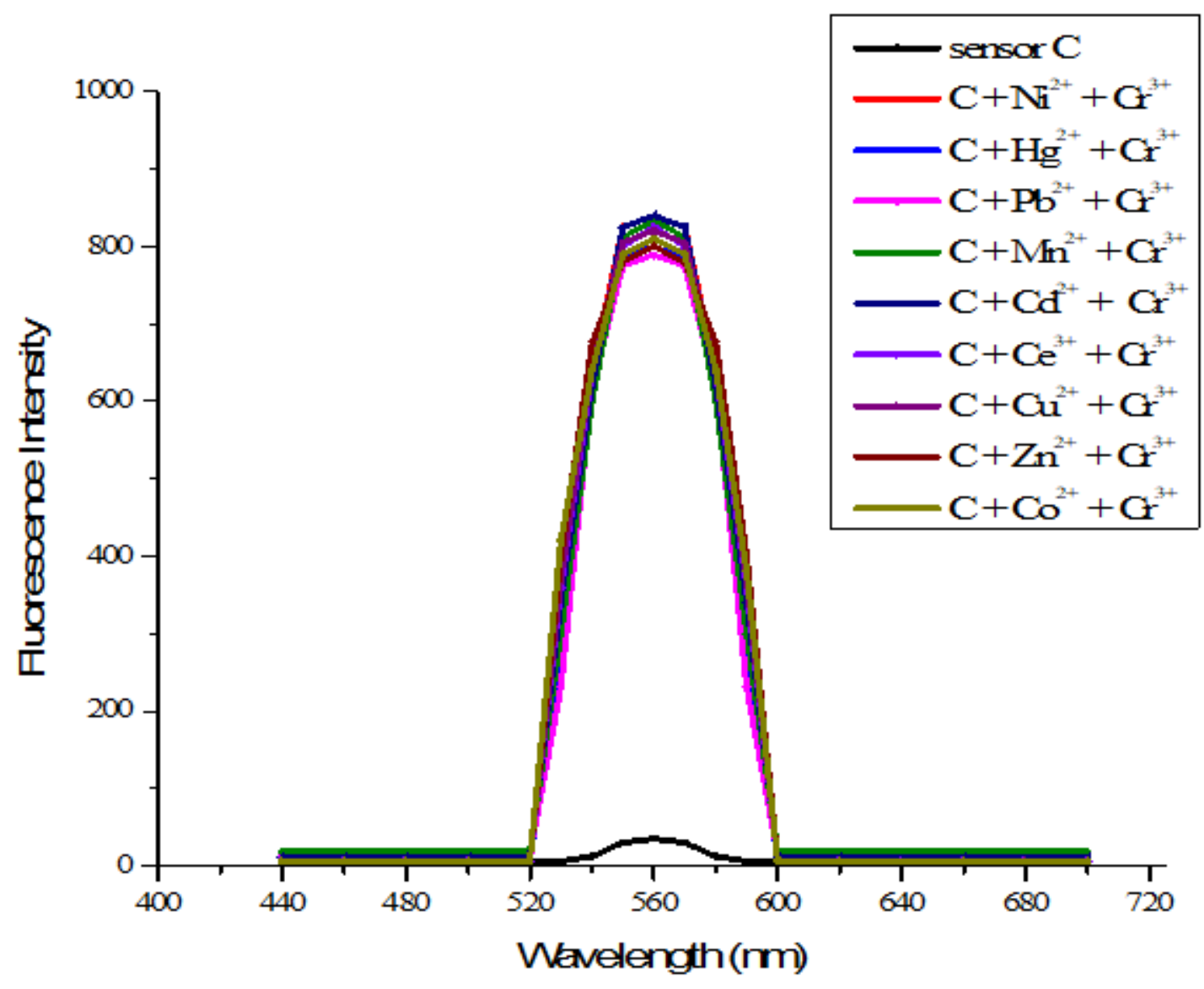

Figure 9

Selective responseof sensor $\mathrm{Cfor} \mathrm{Cr} 3+$ in the presence of interfering metal ions $(\lambda e m=560 \mathrm{~nm})$. 


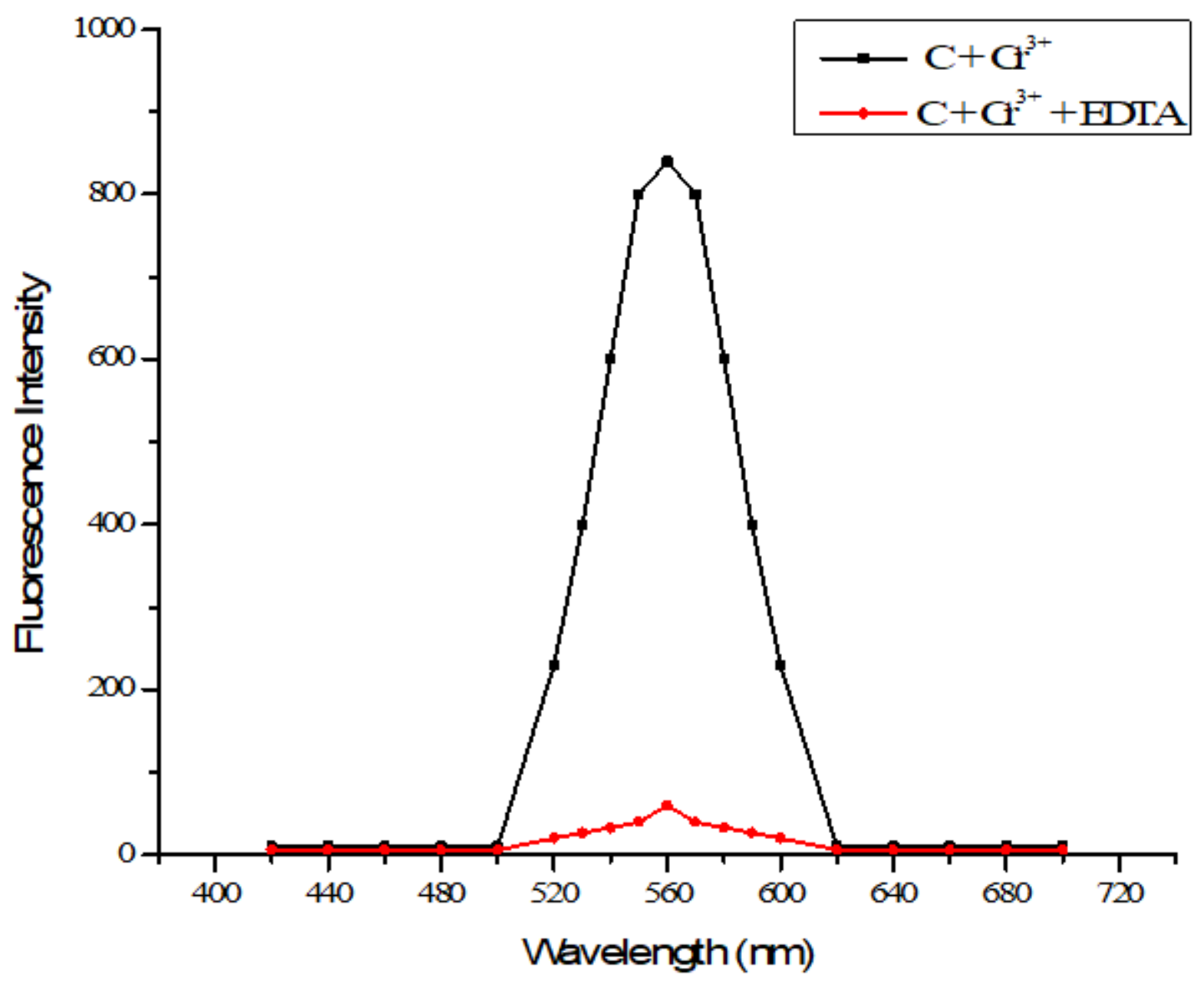

Figure 10

Reversibility experiment of sensor C complex with EDTA at $\lambda$ em560 nm. 


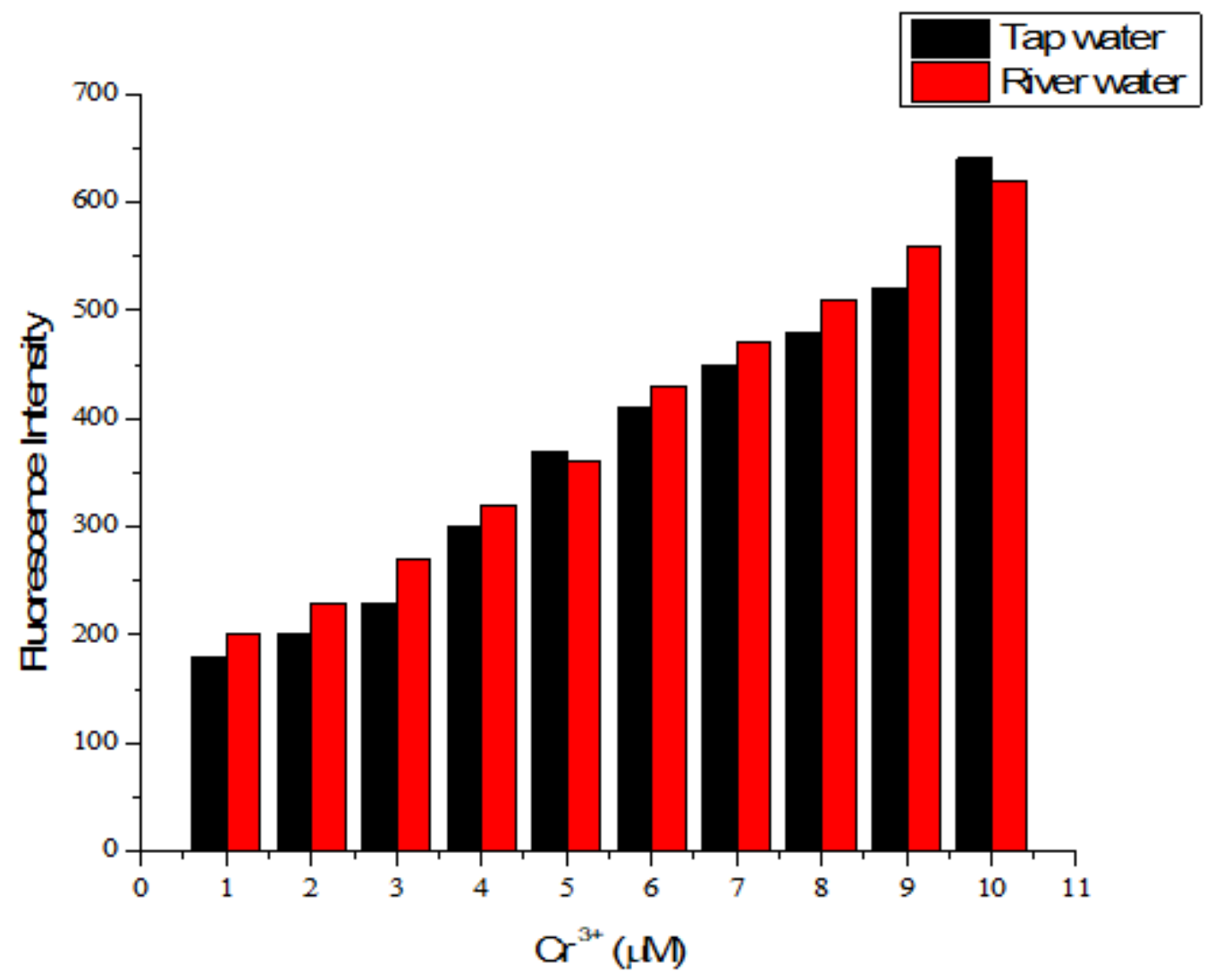

Figure 11

Detection of chromium in real watersamplesat560 $\mathrm{nm}$.

\section{Supplementary Files}

This is a list of supplementary files associated with this preprint. Click to download.

- GraphicalAbstract.png

- Scheme1.png

- Scheme2.png 